\title{
Hundred Million International Units
}

National Cancer Institute

\section{Source}

National Cancer Institute. Hundred Million International Units. NCI Thesaurus. Code C156119.

A unit of biological activity equal to one hundred million international units. 